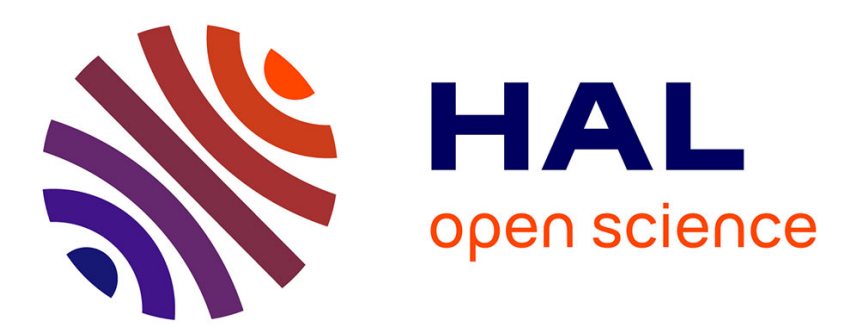

\title{
Diaspora growth and aggregate remittances: an inverted-U relationship?
}

Bernard Poirine, Vincent Dropsy

\section{To cite this version:}

Bernard Poirine, Vincent Dropsy. Diaspora growth and aggregate remittances: an inverted-U relationship?. Applied Economics, 2018, 51 (11), pp.1151-1165. 10.1080/00036846.2018.1524981 . hal02133273

\section{HAL Id: hal-02133273 \\ https://hal.science/hal-02133273}

Submitted on 17 May 2019

HAL is a multi-disciplinary open access archive for the deposit and dissemination of scientific research documents, whether they are published or not. The documents may come from teaching and research institutions in France or abroad, or from public or private research centers.
L'archive ouverte pluridisciplinaire HAL, est destinée au dépôt et à la diffusion de documents scientifiques de niveau recherche, publiés ou non, émanant des établissements d'enseignement et de recherche français ou étrangers, des laboratoires publics ou privés. 
See discussions, stats, and author profiles for this publication at: https://www.researchgate.net/publication/327848715

\section{Diaspora growth and aggregate remittances: an inverted U relationship ?}

Preprint in Applied Economics · September 2018

Dol: 10.1080/00036846.2018.1524981

\section{CITATIONS}

0

2 authors:

University of French Polynesia

38 PUBLICATIONS 585 CITATIONS

SEE PROFILE

Some of the authors of this publication are also working on these related projects:

Economics of small islands View project

Economics of Migrations and Remittances View project

\section{A. Vincent Dropsy \\ University of French Polynesia}

20 PUBlications 137 CITATIONS

SEE PROFILE 


\section{Preprint:}

\section{Diaspora Growth and Aggregate Remittances: an Inverted-U Relationship?}

Bernard Poirine ${ }^{\mathrm{a}}$ and Vincent Dropsy ${ }^{\mathrm{a}}{ }$

${ }^{a}$ University of French Polynesia, Tahiti, French Polynesia

* Corresponding authors. E-mail: vincent.dropsy@upf.pf

Authors' revised and accepted manuscript, to be published in Applied Economics (2019)

Bernard Poirine: Emeritus Professor of Economics, University of French Polynesia, bernard.poirine@upf.pf ,+(689) 87702307

ORCID ID number: 0000-0002-3165-9209

Vincent Dropsy: Associate Professor of Economics, University of French Polynesia vincent.dropsy@upf.pf $\quad+(689) 40803866$

ORCID ID number: 0000-0002-7525-756X

Address: University of French Polynesia, BP 6502, 98702 Faa'a, Tahiti, French Polynesia

Keywords: international migration; remittances; diaspora; gravity model

JEL classification codes: C23, C24, D91, F22, J61.

Declaration of interest: The authors declare that they have no relevant or material financial interests that relate to the research described in this paper. 


\title{
Diaspora Growth and Aggregate Remittances: an Inverted-U Relationship?
}

\begin{abstract}
This paper presents a model in which remittances stem from a decision made jointly by a family coalition of multiple migrants and non-migrants, allowing two alternative interpretations: migrants' altruism or bargaining power. The model predicts that aggregate remittances first increase, reach a maximum, and then decrease as the emigration ratio (migrants/non-migrants) increases. An alternative model of loan repayment arrangement between each migrant and her parents, predicts that aggregate remittances grow monotonously with the emigration ratio. Testing both predictions on a macroeconomic bilateral dataset we find evidence in favour of the first model and an inverted-U relationship between aggregate remittances and the emigration ratio, with a maximum reached at a value of 0.5 . Since many small "MIRAB" island nations are close to or even above this threshold value, this finding is of highly relevant for them since they may experience declining aggregate remittances as the diaspora grows further.
\end{abstract}

Keywords: international migration; remittances; diaspora; gravity model JEL classification: C23, C24, D91, F22, J61.

Word count: 8732 


\section{Introduction}

Migrants' remittances have risen sharply worldwide, increasing almost 6-fold from 98 billion U.S. dollars in 1995 to 580 billion U.S. dollars in 2014, and almost 8-fold for inflows to developing countries from 55 to 427 billion U.S. dollars during the same period (World Bank, 2015). Many poor countries are highly dependent on remittances. For ten countries, remittances were equivalent to at least $20 \%$ of GDP in 2013. Sixteen other countries received inflows greater than $10 \%$ of GDP (World Bank database). Such official figures probably underestimate actual numbers, because informal transfers are often left unrecorded (Freund \& Spatafora 2008, 364; Brown and Jimenez 2015). Many small states are also heavily dependent on migration and remittances. This is particularly true of small island developing states (Amuedo-Dorantes, Pozo, and Vargas-Silva 2010). In small islands such as Grenada, Jamaica, Trinidad and Tobago, Samoa, St Vincent and the Grenadines, Tonga, St. Lucia, St Kitts and Nevis, Cape Verde, the emigration rate of the tertiary educated population ranged from $68 \%$ to $89 \%$. According to De La Croix et al. (2014), the emigration rate for skilled workers in small island developing states averaged $50.8 \%$ and ranged from $15 \%$ to $89 \%$. Feeny, Iamsiaroj and McGillivray (2014) find evidence that remittances have significantly contributed to the rate of economic growth of small island states located in sub-Saharan Africa and in the Pacific region.

While worldwide aggregate remittances steadily increase, remittances received by some small countries, where the emigration rate has been historically very high and the diaspora has settled abroad for many generations, such as Malta, Cyprus, Portugal, now tend to become stable or even decline, even though the diaspora is still very large compared to the resident population. 
Our theory shows that the remittance sent per emigrant is inversely related to the number of emigrant remitters per family, ceteris paribus, giving rise to an inverted-U shaped pattern for total remittances received in the country of origin when the emigration ratio (migrants/non-migrants) increases. We then find empirical evidence that supports this hypothesis.

More precisely, our theory assumes that the family coalition acts strategically when deciding who is going to migrate, who is going to bear the initial cost, and then how the returns are shared between migrants and non-migrants. The decision to emigrate and send remittances is not an individual decision of each migrant, but a joint decision of the family, which comprises migrants and non-migrants. Emigration increases the family's income and intertemporal utility over two periods: the investment period and the return on migration period. The family first decides the optimum amount of human capital investment given to the future migrant children in case of emigration, then incurs the investment cost of emigration, and finally decides how to share the returns on this investment between migrants and nonmigrants.

This theory differs from the traditional "altruistic" assumption that the remitters value the recipients' utility in their own utility function. Rather, it assumes that there are social norms of reciprocity, called "sharing norms pressures" such as in Brown, Leevesb and Prayaga (2014). Such norms are enforced through threats of retaliation against the noncooperating migrant-remitter. Family altruism, trust and loyalty may help enforce the informal contractual arrangement at the least cost, as first suggested by Stark $(1991,220)$. The gains from the parental investment in the children's human capital in the first period are shared between parents and children in the second period, according to the relative bargaining strength of migrants and non-migrants. However, both migrants and non-migrants set "threat points". Migrants want to stop short of equalizing their post transfer income with non- 
migrants (otherwise, there would be no incentive to migrate at all), and non-migrants want to receive some positive transfer as a return on their initial investment for securing education and financing early migration costs of migrants.

We then show that any alternative theory of remittance implying any kind of one to one implicit contract or exchange of service between each migrant child and the non-migrant parents leads to the prediction that the number of other migrant relatives does not affect the per migrant own remittance. We show this in the case of the loan repayment hypothesis (Poirine 1997; Brown and Poirine 2005), whereby parents extend an informal loan to finance their offspring's human capital investment in expectation of a repayment with interest when the migrant children earn higher incomes abroad and send remittances. It has also been shown previously in the case of the insurance hypothesis (Agarwal and Horowitz 2002).

As a result, we have opposite predictions for the two broad theories: if remittances are either altruistic or the result of a bargaining process in a family coalition setting, remittances per migrant decrease with the number of migrant relatives, and aggregate remittances first increase, then decrease with the ratio of remitters to recipients. We do not obtain this prediction with theories implying an individualistic and non-altruistic decision of each migrant, that is, an informal contractual arrangement of insurance, loan or exchange of service between each migrant and the non-migrant relatives.

This means that there is a way to test the two kinds of theories, if we are able to measure aggregate remittances as a function of the number of migrants per recipient. To verify our "family coalition" predictions, we then present an empirical analysis, using a macro database of bilateral remittance flows and migrant stocks for each country pair. We successfully test the predictions of the family coalition theory, yielding an inverted-U curve for the relationship between the emigration ratio and aggregate remittances. 
The paper begins with a short literature review in part 2, then lays out a theory of remittances as a collective decision of the family unit, and a competing theory of remittances as an informal family loan in part 3. Part 4 presents the data and methodology, as well as the regression results. Part 5 proposes some policy implications and a conclusion.

\section{Literature Review}

Interesting reviews of the literature on remittances can be found in Docquier and Rapoport (2006), Yang (2011), Brown and Jimenez (2015). Traditionally, motives for private transfers or remittances fall under two headings: altruism or self-interest.

Altruism implies that remittances should increase with the remitter's income and decrease with the recipient income. Funkhouser (1995), Poirine (2006), and Agarwal and Horowitz (2002) find that under the hypothesis of altruism with multiple migrants in the family, remittances per remitter increase with the number of recipients and decrease with the number of remitters.

There are several possible self-interest motives:

- Repaying parental loan, also called the investment motive (Johnson and Whitelaw 1974; Rempel and Loebdell 1978; Lucas and Stark 1985; Stark 1991; Poirine 1997; Park 2002; Brown and Poirine 2005): families educate children and then send them abroad. This is an investment in human capital with a high rate of return because the children earn a much higher wage in the destination country compared to the origin country. Some of the mutual gains from this informal loan arrangement are shared with the parents: in Brown and Poirine (2005), the parents leave the intertemporal Pareto gains to the children, a behaviour called 'weak altruism'. In addition, the parents' foregone earnings from letting children get an education and go abroad 
instead of working on the family farm (as they should normally do) must be repaid by the migrant children.

- Informal mutual insurance ('risk sharing') arrangement. This motive has been proposed by Stark (1991), Stark and Levhari (1982), Rosenweig and Stark (1989). Agarwal and Horowitz (2002) contrast the predictions under this insurance motive with the conclusions under the altruistic motive. It should be stressed that the coinsurance motive can only be valid for rural to urban migration. In the case of international migration, transfers only go one way, from the migrants to the nonmigrants, because the earning differential is so high that non-migrants do not have the means to insure migrants against an adverse event occurring in the destination country, therefore there cannot be any reciprocal risk sharing agreement in the case of international migration from poor to rich countries.

- Service exchange or inheritance motive: Cox (1987) Cox and Rank (1992), Cox, Eser and Jimenez (1998) show that intrafamilial transfers may be the result of an exchange of money for services in kind, such as taking care of children or elderly parents, or may be sent to preserve the right to inherit land in the country of origin. The inheritance motive is also observed by Bernheim, Shleifer and Summers (1985), by Lucas and Stark (1985) in Botswana, where male migrants remit more to families with a large herd, and by Regmi and Tisdell (2002) in Nepal where migrants remit more when the family has large land holdings.

Most theoretical models used in the economic literature typically assume a migrant (or her parents) behaves with altruism or self-interest and makes a decision based on maximizing her own utility (which may or not depend on the non-migrant recipients' utility), while recipients are passive and have no say on the migrant's decision. The fact that there may be multiple migrants in the same family who act in a coordinated way is often not even considered in the 
theoretical model. Most models assume one migrant's utility function, whether she is altruist or not. It is also often considered that there is only one recipient, or, that the recipient family considered in the migrant's utility function is of unitary size, implying that the number of recipients is of no importance (see for example Docquier et al. (2012), or Osili (2007)). Similarly, Park (2003) assumes a model with one parent and one child and tries to test between the loan repayment and the altruistic hypothesis when observing inter-household transfers in Malaysia. However, his model is not able to derive the theoretical result that altruism and loan repayment do not lead to the same prediction regarding the amount remitted as a function of the number of recipients and remitters, as found by Agarwal and Horowitz (2002, 2038) and Poirine (2006).

To sum up, most recent models of migration and remittances are far from adopting the "family coalition" approach that Stark and Bloom (1985) hailed as the "New economics of labour migration" thirty years ago. A recent plea to return to this view of remittances as a return on the collective family investment in education and emigration was made by Clemens and Ogden (2013): "Migration is, among other things, a strategy for financial management in poor households: location is an asset, migration an investment".

Consistent with the individualistic theoretical approach, most regression analysis do not consider the possibility of several migrants or several recipients. The amount remitted is measured either at the sending end, or at the receiving end (the non-migrant family). As a consequence, it is most often not mentioned if the remittance variable is the remittance received by the family, or the remittance sent by the migrants. 


\section{Theory and Predictions}

This section presents a theory of remittances where a family coalition's decision involves either altruism or bargaining, each member of the family having a specific weight in the collective welfare function, according to her bargaining power or to her altruistic inclination. We then contrast the predictions of this model with the predictions of an alternative model of several one-to-one informal loan arrangements between parents and each migrant child.

\section{The family coalition theory of remittances}

We believe that the family coalition approach can be applied to most countries or regions that are heavily dependent on the remittances of a large diaspora to improve their standard of living, where a formal system of social security or old age pension system does not exist.

The model of remittances here relies on such a view: the family is acting as a "transnational corporation of kin" (Bertram and Watters 1985) and maximizes a collective welfare function, while taking the consumption level of each of its member, at home or abroad, into account.

The decision unit is the family coalition, not the individual migrant or the individual parent sending children migrants abroad. Enforcement of the informal contract is obtained by a mix of altruism, mutual trust, and social pressure, including the threat of retaliation against the non-cooperating migrant, such as the threat of receiving no inheritance, of losing its right to own land at home, or of not being cared for by the family once retired at home (Stark 1991, $221,248)$. From the point of view of the migrants, their threat point is reached whenever their own consumption after migration and transfer would become less than it would be without migration. In other words, migrants should be at least as well off after transfer as non- 
migrants, otherwise there would be no incentive for them to migrate (with the psychological and financial cost this may include) and respect their part of the arrangement.

The family is made up of $m$ migrants and $n$ non-migrants. We take as given the decision to send $m$ migrants abroad, since we are not interested here in modelling the migration decision and educational investment (Poirine 1997; Brown and Poirine 2005), but in the remittance amount sent once the diaspora has settled in the destination countries.

Each adult migrant $i$ sends $T i$ to his family back home, to be divided equally among nonmigrant adults.

The consumption of the typical migrants is:

(1) $C i=Y i-T i$

Where $Y i$ is the migrant's income and $T i \geq 0$

The consumption of the typical non-migrant at home is augmented by the transfers from each of the $m$ migrants, divided equally among the $n$ non-migrants:

(2) $C_{j}=Y_{j}+(m / n) T_{i}$

Where $Y_{j}<Y_{i}$ is the non-migrant's income, and $m / n$ is the ratio of migrants to non-migrants, hereafter defined as the emigration ratio $R$ (note that it is not equal to the migration rate $m / m+n)$

The collective welfare function of the transnational family is specified as an extended Cobb Douglas function (if $m=n=1$ it becomes a simple Cobb-Douglas function):

$$
W\left(C_{i}, C_{j}\right)=\prod_{1}^{m} C_{i}^{(1-\propto)} \cdot \prod_{1}^{n} C_{j}^{\alpha}
$$


The first partial derivative of $W$ with respect to any $C_{i}$ or $C_{j}$ is positive, the second derivative is negative, yielding an increasing concave function of each family member's consumption.

Each migrant's consumption is valued $C_{i}^{(1-\propto)}$ in $W$, while each non-migrant's consumption is valued $C_{j}^{\alpha} . \alpha$ is the weight of non-migrants in the welfare function. A value of $\alpha=0.5$ means that migrants and non-migrants have an equal weight. Obviously $0<\alpha<0.5$, since $\alpha>0.5$ would lead to migrants' post transfer income being less than non-migrants' income (the ratio of net post-transfer income is equal to $(1-\alpha) / \alpha$ as shown in equation (7) below), something that would be very hard for migrants to accept. On the contrary, we presume that $\alpha$ should be significantly lower than 0.5 , to compensate migrants for the cost, risk, and hardship of migration. In other words, we expect them to require, as a condition to stay in the coalition, a significantly higher average consumption level, after transfer, than the non-migrants' consumption level.

The altruistic interpretation of $\alpha$ is that it measures the intensity of migrants' altruism toward non-migrants. However ethnographic studies tend to show that remittances are not always given out of altruism, but more often as a result of social norms that make it an obligation to respond to money requests made by parents and relatives (Carling 2014).

The non-altruistic "coalition and bargaining arrangement" interpretation of $\alpha$ is that (1- $\alpha)$ is the bargaining power of migrants and $\alpha$ is the bargaining power of non-migrants. The family coalition first maximizes the family inter-temporal utility from human capital investment and migration (as shown in Poirine 1997), and then shares the Pareto gains from education and migration between migrants and non-migrants in order to maximize the collective welfare function $W$. 
Assume for simplicity that all migrant family members have identical incomes $Y_{i}$ and that all non-migrants have identical incomes $Y_{j}$, which implies that each migrant sends the same amount $T i$. This implies that all migrant family members have the same consumption $C_{i}$ from (1), and that all non-migrants' family members have the same consumption $C_{j}$ from (2). Therefore equation (3) simplifies to:

(3') $W\left(C_{i}, C_{j}\right)=m C_{i}^{(1-\propto)} n C_{j}^{\propto}$

Let us take the natural logarithm of $W$ to get a log linear additive expression for the family welfare and replace $C_{i}$ and $C_{j}$ by their values in (1) and (2):

$$
\operatorname{Ln}(W)=m(1-\alpha) \operatorname{Ln}\left(Y_{i}-T_{i}\right)+n \alpha \operatorname{Ln}\left(Y_{j}+\frac{m}{n} T_{i}\right)
$$

Since the natural logarithm is an increasing monotonous concave function, maximizing $W$ and $\operatorname{Ln}(W)$ is equivalent.

To maximize $\operatorname{Ln}(W)$, we set equal to zero the derivative with respect to $T_{i}$, taking $m$ and $n$ as given parameters. The second order derivative being negative, this yields a first order condition for a maximum.

$$
\frac{\partial L n(W)}{\partial T_{i}}=-\frac{m(1-\propto)}{\left(Y_{i}-T_{i}\right)}+\frac{n \propto \frac{m}{n}}{Y_{j}+\frac{m}{n} T_{i}}=0
$$

The first order condition from (5) is:

$$
\beta=\frac{1-\propto}{\propto}=\frac{Y_{i}-T_{i}}{Y_{j}+\frac{m}{n} T_{i}}
$$

The ratio $\frac{1-\alpha}{\alpha}$, which measures the relative weight of migrants $(1-\alpha)$, compared to nonmigrants $(\alpha)$ in the collective welfare function $W$, is now called $\beta$, and is equal to the ratio on the right of (6) which is the "target" post-transfer consumption ratio that maximizes $\operatorname{Ln}(W)$. 
Migrants from the same family now act as if they adjusted their transfer $T_{i}$ in a coordinated way in order to reach this "target" consumption ratio at all times.

To illustrate this, if $\alpha=0.5, \beta=1$, then we should have, after transfer, an equal per capita consumption of the migrants and non-migrants. In other words, migrants adjust $T_{i}$ until this "target" consumption ratio $\beta=1$ is obtained after transfer.

From (6) we derive $T_{i}{ }^{*}$, the value of $T_{i}$ that maximizes $L n(W)$, after defining $R=m / n$ as the emigration ratio.

(7) $T_{i}{ }^{*}=\frac{Y_{i}-\beta Y_{j}}{1+\beta R} \quad$ where $\beta \geq 1$ is the "target" post-transfer consumption ratio of equation (6), with $\beta=\frac{1-\alpha}{\alpha}$.

Since we want $T_{i}^{*} \geq 0$, we need $Y_{i} \geq \beta Y_{j}$, or (since $\left.\beta>0\right) \quad 1 \leq \beta \leq \frac{Y_{i}}{Y_{j}}$

The remittance function (7) has the following partial derivatives:

$$
T_{i}^{*}=F\left(\begin{array}{cccc}
Y_{i} & Y_{j} & R & \beta \\
+ & - & - & -
\end{array}\right)
$$

Therefore, the model yields the following first prediction:

As the ratio $R$ of remitters to recipients increases, the transfer per emigrant $T_{i}{ }^{*}$ declines.

Figure 1 illustrates this negative relationship with a simple simulation with a population $(m+n)$ of $100, \alpha=0.5(\beta=1), Y_{i}=24,000$ US $\$, Y_{j}=3,000$ US $\$$ (these two rounded per capita GDP being close to those of destination and origin countries in the sample of available observations for the remittances), and $R$ varying from 0 to $200 \%$ (100\% corresponds to the point of equality between transfer sent per emigrant and transfer received by non-migrants). A value of $\beta=1$ means that migrants have adjusted their individual 
remittances $T_{i}{ }^{*}$, so that the post-remittances consumption per migrant (also indicated on figure 1) is equal to the post-remittances consumption per non-migrant.

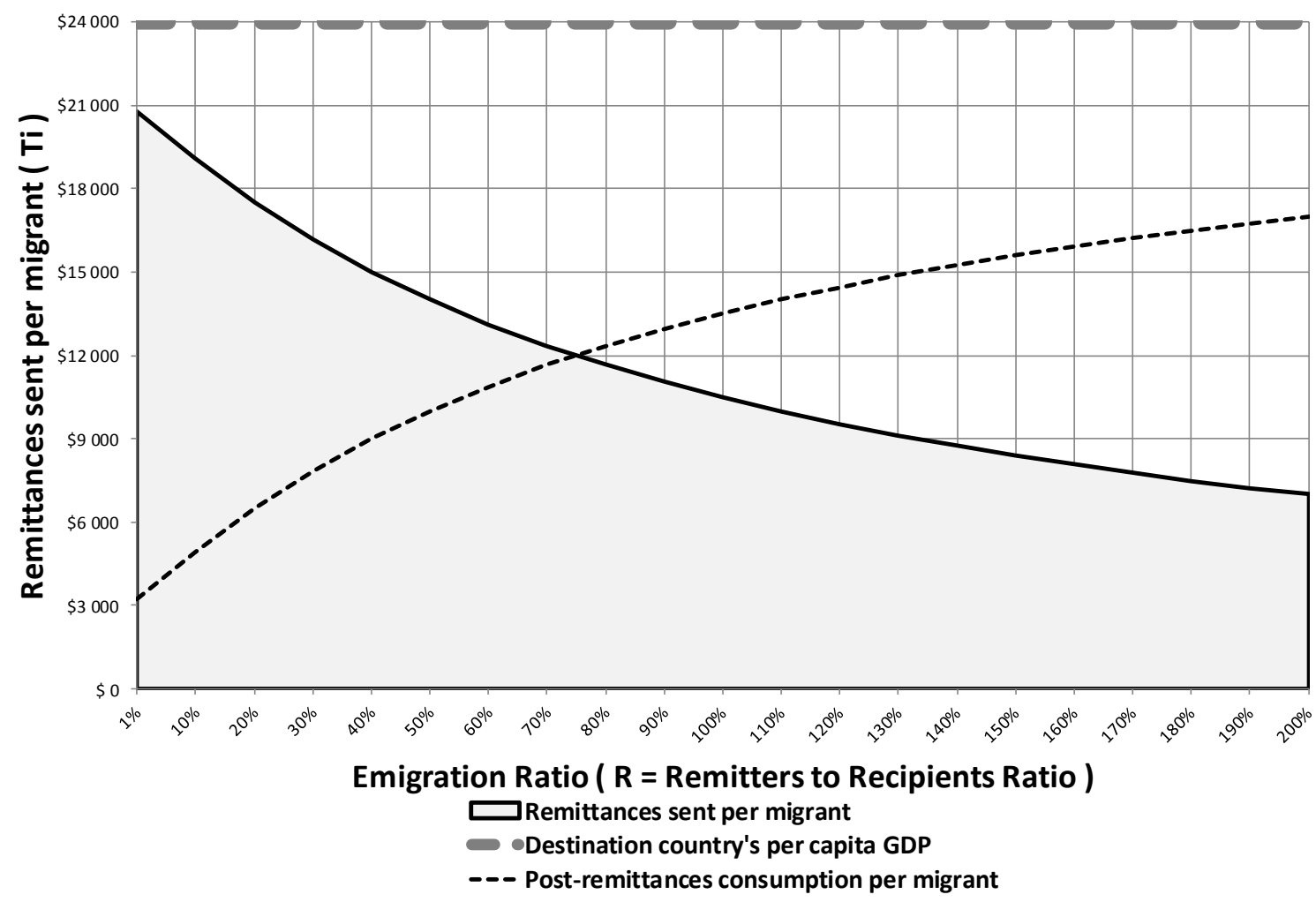

Figure 1: Simulation of remittances sent per migrant as a function of the emigration ratio

The remittance received per recipient is:

$$
T_{j}^{*}=\left(\frac{\mathrm{m}}{\mathrm{n}}\right) T_{i}^{*}=\mathrm{R} . T_{i}^{*}=\frac{R \cdot Y_{i}-\beta \cdot R \cdot Y_{j}}{1+\beta \cdot R}=\frac{Y_{i}-\beta . Y_{j}}{\frac{1}{R}+\beta}
$$

Therefore, as expected, $T_{j}^{*}$ increases with $Y_{i}$, decreases with $Y_{j}$, decreases with $\beta$, but, most importantly, as R increases, the denominator tends toward $\beta$, and $T_{j}^{*} \rightarrow \frac{Y_{i}-\beta . Y_{j}}{\beta}=\frac{Y_{i}}{\beta}-Y_{j}$

The second prediction of the model can be stated as follows:

As the ratio $R$ of remitters to recipients increases, the transfer per recipient $T_{j}^{*}$ is an increasing concave function of $R$, bounded above by a horizontal asymptote, $\frac{Y_{i}}{\beta}-Y_{j}$, where 
the remittance received per recipient $T_{j}^{*}$ is just enough to bring the recipient to a posttransfer income just equal to a fraction $\beta$ of the average migrant's income.

Using the same numerical simulation as above, Figure 2 shows this concave shape of remittances per recipient and of post-remittances consumption for the same non-migrant.

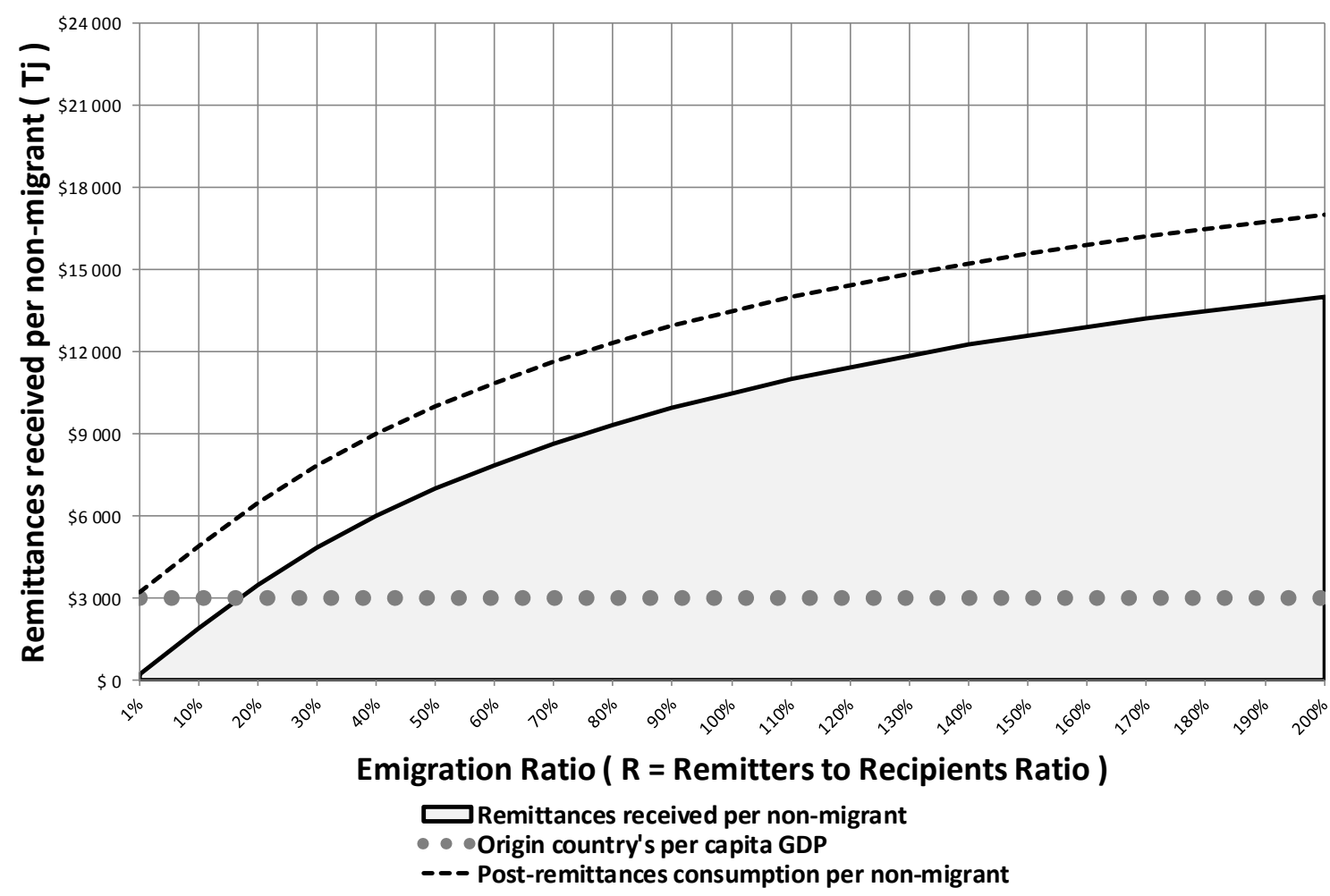

Figure 2: Simulation of remittances received per non-migrant as a function of the emigration ratio

This prediction of the model is important for migration policy when the emigration rate (and emigration ratio) is already very high, because it means that an ever-rising diaspora does not mean an indefinitely rising transfer per recipient at home, for a given value of the parameter $\alpha$. 
In other words, non-migrants will never earn more than migrants after transfer, even if many migrants send remittances to a few non-migrant family members, because the money transfers sent are progressively adjusted downward as R increases, in order to keep the "target" consumption ratio $\beta$ constant.

Now let us turn to total aggregate remittances sent by the diaspora (TT) of a family:

(9) $T T^{*}=m T_{i}^{*}=m \cdot \frac{Y_{i}-\beta * Y_{j}}{1+\beta * R}$

If we assume that the total number of migrants and non-migrants $m+n$ is constant (and equal to the total population "pop" of a family (i.e., migrants and non-migrants), then $m$ can be rewritten as a function of pop and $\mathrm{R}$.

(10) $m=\frac{p o p}{1+\frac{1}{R}}$

As a result, the total aggregate remittances become a function of $\mathrm{R}$ :

(11) $T T^{*}=\operatorname{pop} \cdot \frac{Y_{i}-\beta * Y_{j}}{\left(1+\frac{1}{R}\right) *(1+\beta * R)}$

Using the same numerical simulation as above, Figure 3 shows that aggregate remittances follow an inverted-U curve as $\mathrm{R}$ increases, with a maximum at $R=\frac{1}{\sqrt{\beta}}$, obtained by setting equal to zero the partial derivative of (11) with respect to R for a given total family population pop $=m+n$. The lower $\alpha$ (the higher $\beta)$, the sooner comes the maximum of the aggregate remittance curve as $\mathrm{R}$ increases. Furthermore, aggregate remittances converge to zero when $\mathrm{R}$ increases to infinity, yielding an inverted-U relationship with $\mathrm{R}$, although with a stretching tail. 


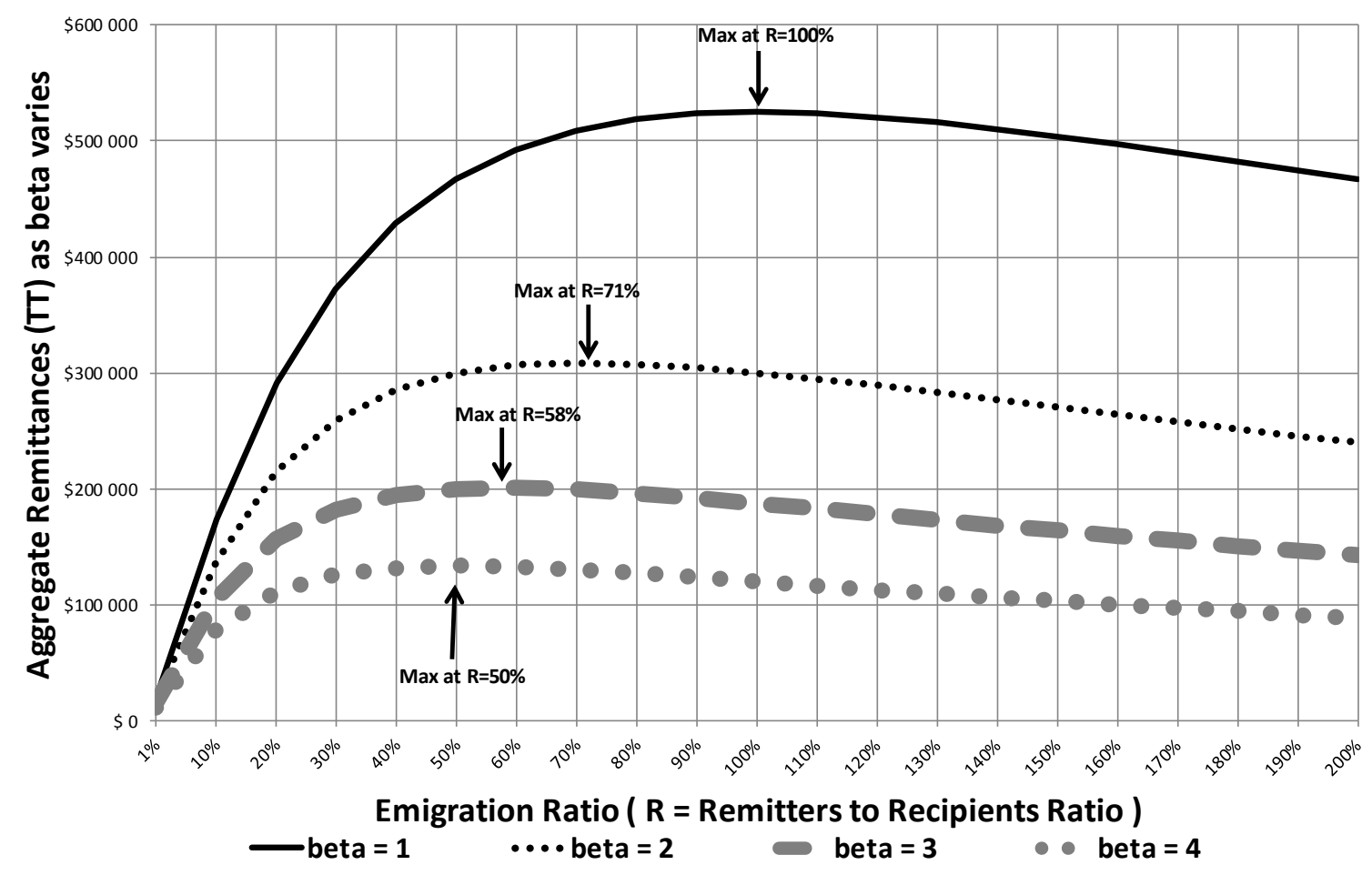

Figure 3: Aggregate remittance functions as the target post transfer ratio $\beta$ varies

This leads to a third proposition:

As the ratio $R$ of diaspora remitters to non-migrant recipients increases, aggregate remittances $\mathrm{TT}^{*}$ first increase; reach a maximum and then decrease. This maximum is reached sooner and sooner, as $\beta$ (the target consumption ratio) increases.

This result is important for migration policy, since it means that old emigration countries, such as Portugal, Malta, Cape Verde, Samoa, Tonga, Kiribati, Cook islands, Wallis and Futuna, Montserrat, which at first had their domestic growth rate boosted by remittances as $R$ began to increase, may find out after a while that the remittance boom turns to bust when $R$ overshoots the value yielding a maximum of the aggregate remittance curve. Then there is less and less family members left to send remittances to, most of them having been reunited with the migrant family. This is not due to a weakening of the altruistic feelings ( $\alpha$ has not 
changed): it is a mere result of the mechanics of our remittance model when the family is the decision unit.

\section{The one to one loan repayment or co-insurance contract arrangement theory yields}

\section{opposite predictions}

In contrast with the family coalition theory above, assuming either altruism or a negotiation based on bargaining power, another hypothesis is that each migrant repays an educational debt to her parents, either by working for free on the farm with them, or by migrating and sending remittances back to the parent household. This theory is based on the utility maximizing behaviour of the non-migrant parents over two periods (Poirine 1997, Brown and Poirine 2005). During the first period the parents are active, earn an income and educate the children. In the second period the parents send the children in high-income destination countries and are repaid (with interest) for the cost of education incurred in the first period. The migrant children are driven to comply by social norms, and by the different threats of retaliation already detailed above. In countries with no formal security system and no mandatory pay as you go pension system, the social norm (and in some cases the law itself) obliges the parents to provide for their children, and the children to provide for their elderly parents.

Assume $m$ parents with index $i, n$ children with index $j$, and two periods: period 0 lasting (1- $\alpha)$, and period 1 lasting $\alpha$.

In the first period, the $m$ parents are working and earning $y_{i, 0}$, out of which each of them donate $T$ for the education of their $n$ children ( $T$ is the monetary equivalent of time spent in caring for the children, plus the cost of formal education and of the children's 
consumption). Each of the $n$ children receives from the $m$ parents (in kind and in consumption spending): $(m / n) T$.

In the second period, the $m$ parents retire and have no income. The $n$ children repay the educational loan with interest, in kind if they live with their parents (by working on the farm), or by sending remittances if they migrate. The interest rate is $r$, the market rate of interest for example (children could not borrow from the banks in the first period since they had no collateral). Therefore, each child repays to each parent $(m / n)(1+r) T$, and each of the $m$ parents receives from the $n$ children $(n / m)(m / n)(1+\mathrm{r}) T=(1+\mathrm{r}) T$, where $1+r$ is one plus the market rate of interest to borrow in the first period a sum repaid in the second period.

Thus, the consumption of each parent and child are:

First period 0 Second period 1

$C_{i, 0}=y_{i, 0}-T$

$$
C_{i, 1}=(1+r) \cdot T
$$

$C_{j, 0}=\frac{m}{n} T$

$$
C_{j, 1}=y_{j, 1}-\frac{m}{n}(1+r) \cdot T
$$

Parents maximize an inter-temporal utility function, the consumption of the second period being discounted by $(1+r)$. The weight of the first period $(1-\alpha)$ and of the second period $(\alpha)$ are proportional to the length of the respective periods relative to the total length of both periods, i.e. the parents' lifetime.

$U\left(C_{i, 0}, C_{i, 1}\right)=C_{i, 0}^{(1-\alpha)} \cdot\left(\frac{C_{i, 1}}{1+r}\right)^{\propto}$

Taking the logarithm of $U$, we get a log linear function $\operatorname{Ln}(U)$. Maximizing $\operatorname{Ln}(U)$ is equivalent to maximizing $\mathrm{U}$ :

$$
\operatorname{Ln}(U)=(1-\propto) \ln C_{i, 0}+\propto \ln \left(\frac{C_{i, 1}}{(1+r)}\right)=(1-\propto) \ln \left(y_{i, 0}-T\right)+\propto \ln \left(\frac{(1+r) \cdot T}{1+r}\right)
$$


Taking the derivative and setting it to zero we get a first order condition for a maximum of $\operatorname{Ln}(U):$

$\frac{\partial \ln U}{\partial T}=-\frac{(1-\propto)}{y_{i, 0}-T}+\frac{\propto}{T}=0$

The first order condition yields:

$$
T^{*}=\alpha \cdot y_{i, 0}
$$

This time, the optimal remittance does not depend on the ratio of remitters to recipients, as in the previous model, nor does it depend on the income of the remitters. If parents have a positive income $y_{i, 1}$ in the second period, it can be shown that $T^{*}$ is inversely related to this income. Moreover, $T^{*}$ is proportional to the recipients' first period income, for richer parents are able to make a larger educational loan to their children. This implies that richer family (for example, families with more land and a higher income from farming) would tend to receive more remittances than poor families, which is again a prediction opposite to that of the first model.

Therefore, there is a simple way to test between the "altruism/bargaining" theory and the "loan repayment" theory: in the first case remittances sent per remitter decrease with the recipient's income and with the number of remitters, and aggregate remittances increase, reach a maximum and then decrease with the remitter/recipient ratio. In the second case, the remittance per remitter increases with the recipient's income, but does not depend on the number of remitters, and aggregate remittances increase monotonically with the number of remitters. 


\section{Empirical Evidence from Aggregate Bilateral Remittance and Emigration Data}

This section tests the "altruism/bargaining" theory through its inverted-U relationship between the emigration ratio $\mathrm{R}$ (i.e., diaspora to labour force at origin) and aggregate remittances. The theory shows this relationship for a single family. Is it possible to test it using macroeconomic data on the ratio of the migrant stock from each origin country to the total labour force of this country? In any given origin country o, let us call the average family ratio $R_{f o}$ for the emigrant sending families, and the percentage of families sending emigrants $S_{o}$. The average origin country ratio $R o$ for any 100 families equals $S o R_{f o}$. As a consequence, the average country ratio $R_{o}$ may be higher in country A than in country $\mathrm{B}$, either because each family sends more migrants in country A, or because the percentage of migrant sending families is higher in this country. In the absence of macro data on the latter variable, we reasonably assume that $S o$ and $R_{f o}$ are correlated, which means that in countries with a higher percentage of migrant sending families, those families have a higher ratio of migrants to nonmigrants. In this case, $R o$ and $R_{f o}$ will also be correlated, and the microeconomic theory can be validly tested using macro data, using $R o$ as a proxy for $R_{f o}$.

\section{Methodology}

Gravity models have been increasingly used to study international migration, with the availability of bilateral data for flows and remittances, as Beine et al. (2014) explain. Indeed, gravity models are especially useful to estimate the effects of income in the origin country of migrants and income in their destination country, as well the distance between the two countries, on migrations and remittances. Wage differentials between the origin and the destination countries can be a powerful magnet for migration flows and remittances. At a macroeconomic level, a lower average per capita GDP at origin and a higher average per capita GDP at destination should cause higher level of remittances. Distance between the two 
countries tends to be an obstacle to flows of goods, money, and people. Head and Mayer (2014) review the history, micro-foundations and theory-consistent estimation of gravity models, in particular, when they are applied to international trade.

However, they address econometric issues that gravity models encounter, when they are also applied to migration and remittances, and compare different methods of estimation, such as a Poisson Pseudo-Maximum Likelihood (PPML) technique proposed by Santos Silva and Tenreyro (2006, 2011). Anderson (2011) presents a state-of-the-art review of the gravity model and offers an overview of its application to migration. He also concludes that: "The problem of zeroes in the trade and factor flows data has been addressed with some success, particularly by Helpman, Melitz and Rubinstein". Indeed, Helpman et al. (2008) have proposed a two-stage Heckman estimation procedure to correct for sample selection bias in estimating trade flows, as well as an exclusion restriction (i.e. at least one variable in the first stage estimation that is not included in the second stage estimation) for identification purposes. In our study of remittances, the first stage consists of estimating a Probit equation on a dummy variable for positive remittances from one country to another, while the second stage yields consistent estimates for the determinants of remittances. Given that the dataset used consists of bilateral remittances between two countries, a zero observation corresponds to an absence of household wishing to remit, and thus to a type 2 non-remitting household, for which Heckman's two-step model is particularly appropriate. In our empirical analysis, we will compare the signs and levels of significance of the PPML estimates with those of two estimates from the Heckman selection model, from a two-step (H2S) and a maximum likelihood (HML) method. 


\section{Data and descriptive statistics}

First, we use a dataset on bilateral remittances by country pairs, migrant stock at destination country and migrants' education level kindly provided to us by Docquier, Rapoport and Salomone (DRS). They have merged five databases on bilateral remittances from 46 countries of origin to 52 countries of destination over the period from 1985 to 2005 . The detailed description of the method used to do this is in Docquier et al. (2012). DRS chose to include zeroes whenever there was no data available for bilateral remittances. We used a slightly different method to impute 6500 zeroes from the original data, with the additional condition that the number of bilateral emigrants should be less than $1 \%$ of the labour force.

Second, we extract data on bilateral migration stocks per education level from the database built by Artuc et al. (2015) based on census data collected for 100 countries in 2000 and 60 countries in 1990, and generously made available by the authors (see Docquier 2014).

Third, we obtain data on bilateral distances between 225 countries, as well as on their economic ties (trade agreement), financial ties (common currency), cultural ties (common language) and institutional ties (common colonizer) from databases of the CEPII (2014).

Fourth, we get data on GDP and population for the origin and destination countries, as well as the world migrant stock (diaspora) from the origin countries from the World Economic Outlook database of the International Monetary Fund (2014).

Our model implies that emigrants send part of their earnings to the family back home. However, for some country pairs, the average remittance sent per migrant exceeds the average income per capita in the host country. This may happen if the migrants' average income is vastly superior to that of the local residents, for example when in low income countries, most of the migrant workers are in fact expatriate diplomats, NGO workers, or executives working for foreign companies on short term contracts, who are transferring their savings to a bank 
account back home. Such high-income migrants working in low income countries have a very different set of motivations and their transfers cannot be considered as remittances to help their low-income family back home. Therefore, we chose to exclude from the sample the observations pertaining to country pairs for which remittances per migrant from country A to country B exceeded the average income per capita of country A. We also exclude from the sample the observations for which GDP per capita in the destination country is inferior or equal to GDP per capita in the origin country, since the condition $T i^{*} \geq 0$ implies $Y_{i} \geq \beta Y_{j}$, and thus (since $\beta>1$ ) $1 \leq \beta \leq \frac{Y_{i}}{Y_{j}}$ as mentioned above (cf. equation 7). As a result, we are left with 6291 observations, after having removed the double observations with two different values from two different sources.

The definitions and summary statistics of the variables used in our estimated model are reported in Table 1. Note that when defining these variables, we stand from the viewpoint of the representative migrant: the origin country $o$ is where the migrant comes from and is expected to be a remittance-receiving country, whereas the host or destination country $d$ is where the migrant emigrates to and is expected to be a remittance-sending country. 
Table 1 : List of variables and summary statistics

\begin{tabular}{|c|c|c|c|c|c|}
\hline Definition & Unit & N.Obs. & Mean & Max. & $\begin{array}{l}\text { Std. } \\
\text { Dev. }\end{array}$ \\
\hline $\begin{array}{l}\text { Aggregate remittances sent from country } \mathrm{d} \\
\text { to country o (non-zero observations) }\end{array}$ & bn.US\$ & 360 & 219 & 6400 & 764 \\
\hline $\begin{array}{l}\text { Remittances per migrant sent from country } \\
\text { d to country o (non-zero observations) }\end{array}$ & US\$ & 395 & 793 & 7465 & 1116 \\
\hline Emigrants (diaspora) from country o & units & 8899 & 426739 & 1679606 & 426148 \\
\hline $\begin{array}{l}\text { Emigrants in country } \mathrm{d} \text { coming from } \\
\text { country o }\end{array}$ & units & 8899 & 12127 & 1163 & 59311 \\
\hline $\begin{array}{l}\text { Emigration Ratio from country o = } \\
\text { Diaspora / Labour Force (over } 25 \text { years } \\
\text { old) }\end{array}$ & $\%$ & 99 & $6.5 \%$ & 88 & $9.9 \%$ \\
\hline $\begin{array}{l}\mathrm{H} 1 \text { = Emigrants with Tertiary education / } \\
\text { Total Emigrants }\end{array}$ & $\%$ & 6836 & $31.5 \%$ & $100 \%$ & $21.4 \%$ \\
\hline Total population residing in country o & million & & 57.8 & 131 & 126.0 \\
\hline Total population residing in country $\mathrm{d}$ & million & 8899 & 24.5 & 296.0 & 39.6 \\
\hline Nominal GDP per capita in country o & US\$ & 8899 & 3288 & 44218 & 4839 \\
\hline Nominal GDP per capita in country d & US\$ & 8754 & 18554 & 80918 & 13421 \\
\hline $\begin{array}{l}\text { Geodesic distance between the capital } \\
\text { cities of country o and country d }\end{array}$ & $\mathrm{km}$ & 8899 & 5576 & 18953 & 3822 \\
\hline $\begin{array}{l}\text { Relative transaction cost of sending US\$ } \\
200 \text { from country d }\end{array}$ & $\%$ & 8899 & $6.5 \%$ & $18.0 \%$ & $5.0 \%$ \\
\hline
\end{tabular}

\section{Empirical model and results}

The Heckman selection equation specifies the decision of the migrants' population residing in a country of destination " $\mathrm{d}$ " to remit or not to remit to their country of origin "o", with a dummy variable which depends on the following variables, after preliminary investigation:

Dummy for positive bilateral Remittances from o to $\mathrm{d}=$ $c_{d}+a_{1} \log$ (Number of emigrants from o to $\left.d\right)+a_{2} \log$ (GDP per capita of country $d$ ) $+\mathrm{a}_{3} \log ($ Distance from o to $\mathrm{d})+\mathrm{a}_{4}$ Relative transaction cost + Time dummies

This first-step selection model below is estimated with a Probit regression, and its empirical results are shown on the left side of Table 2. 
Table 2: Determinants of aggregate remittances

\begin{tabular}{|c|c|c|c|c|}
\hline \multirow{3}{*}{$\begin{array}{l}\text { Heckman selection model } \\
\text { Dependent variable } \\
(\mathrm{o}=\text { origin country; } \\
\mathrm{d}=\text { destination country })\end{array}$} & \multirow{3}{*}{$\begin{array}{c}\begin{array}{c}\text { Selection } \\
\text { equation }\end{array} \\
\text { Dummy for } \\
\text { Positive } \\
\text { Remittances }\end{array}$} & \multicolumn{3}{|c|}{ Response equation } \\
\hline & & \multicolumn{2}{|c|}{ Ln(Remittances) } & \multirow{2}{*}{$\begin{array}{l}\text { Remittances } \\
\text { PPML }\end{array}$} \\
\hline & & H2S & HML & \\
\hline $\log ($ Number of emigrants from o to $d)$ & $\begin{array}{l}0.82 * * * \\
(28.5)\end{array}$ & & & \\
\hline Emigration ratio $(\mathrm{R})$ & & $\begin{array}{l}14.0 * * * \\
(5.92)\end{array}$ & $\begin{array}{l}13.1 * * * \\
(4.25)\end{array}$ & $\begin{array}{l}100.4^{* * *} \\
(7.34)\end{array}$ \\
\hline Emigration ratio squared $\left(\mathrm{R}^{2}\right)$ & & $\begin{array}{l}-13.9 * * * \\
(4.42)\end{array}$ & $\begin{array}{l}-13.3 * * * \\
(4.92)\end{array}$ & $\begin{array}{l}-301.7^{* * *} \\
(5.23)\end{array}$ \\
\hline $\log ($ Labour force + emigrants from o $)$ & & $\begin{array}{l}1.53 * * * \\
(10.1)\end{array}$ & $\begin{array}{l}1.46^{* * * *} \\
(7.62)\end{array}$ & $\begin{array}{l}1.38 * * * \\
(3.22)\end{array}$ \\
\hline Log(GDP per capita of country d) & $\begin{array}{l}0.88 * * * \\
(6.78)\end{array}$ & $\begin{array}{l}1.85^{* * * *} \\
(9.69)\end{array}$ & $\begin{array}{l}1.79 * * * \\
(5.34)\end{array}$ & $\begin{array}{l}3.90 * * * \\
(7.95)\end{array}$ \\
\hline Log(GDP per capita of country o) & & $\begin{array}{l}-0.21 \\
(1.58)\end{array}$ & $\begin{array}{l}-0.23^{*} \\
(1.77)\end{array}$ & $\begin{array}{l}-0.89 * * * \\
(2.85)\end{array}$ \\
\hline Emigrants' human capital $(\mathrm{H})$ & & $\begin{array}{l}3.94 * * * \\
(2.80)\end{array}$ & $\begin{array}{l}3.95 * * * \\
(3.27)\end{array}$ & $\begin{array}{l}4.85^{*} \\
(1.84)\end{array}$ \\
\hline Emigrants' human capital squared $\left(\mathrm{H}^{2}\right)$ & & $\begin{array}{l}-2.33 \\
(1.45)\end{array}$ & $\begin{array}{l}-2.38^{*} \\
(1.85)\end{array}$ & $\begin{array}{l}0.05 \\
(0.02)\end{array}$ \\
\hline $\log ($ Distance from o to $\mathrm{d})$ & $\begin{array}{l}-0.59 * * * \\
(8.31)\end{array}$ & & & \\
\hline Relative transaction cost (from d) & $\begin{array}{l}-3.67 * * * \\
(3.95)\end{array}$ & & & \\
\hline Constant & $\begin{array}{l}-14.1 \\
(11.2)\end{array}$ & $\begin{array}{l}-25.3 * * * \\
(7.00)\end{array}$ & $\begin{array}{l}-23.2 * * * \\
(3.51)\end{array}$ & $\begin{array}{l}-49.2 * * * \\
(4.62)\end{array}$ \\
\hline
\end{tabular}

Notations: H2S = Heckman's 2-step; HML = Heckman's Maximum Likelihood;

PPML $=$ Poisson Pseudo-Maximum Likelihood

Sample: 6291 available observations, including 286 non-zero observations. and 6005 zeroes. $\mathrm{t}$-statistics are indicated between parentheses below the coefficients.

$* * *, * *$, and $*$ imply significance at $1 \%, 5 \%$, and $10 \%$ level. 
First, it is more likely that remittances will flow if there are more migrants. Also, Docquier et al. (2014) show that the stock of existing migrants, taken as a measure of information and networking, facilitates potential migration. It can be safely assumed that the same informational effect can improve potential remittances. Our results indicate that a $10 \%$ rise in the number of migrants very significantly increase the probability of remitting by $8.2 \%$. Higher wages of emigrants should also improve their likelihood of remitting part of their earnings to their families at home. Indeed, a 10\% higher growth of GDP per capita in the destination country, a proxy for these foreign wages in a country of destination, significantly raises its probability of remittances by $8.8 \%$. The distance between the origin and destination countries can be considered as a proxy for the cost of remitting and has a very significant negative effect on the decision to remit: a $10 \%$ increase in this distance reduces the probability of remitting by $5.9 \%$. The percentage transaction cost for sending US\$ 200 from a destination country is also a significant barrier to the willingness to remit, since a rise of this relative cost by 10 percentage points lowers the probability of remitting by $3.7 \%$.

The Heckman response equation specifies the value of aggregate remittances from a population of migrants residing in a country of destination " $\mathrm{d}$ " to their country of origin "o", as a function of the following variables:

Log $($ Aggregate remittances from o to $\mathrm{d})=$ $c_{a}+b_{1}$ Emigration ratio $(R)+b_{2}$ Emigration squared ratio $\left(R^{2}\right)$

$+b_{3} \log$ (Population from $\mathrm{o}=$ labour force at origin + emigrants from o)

$+b_{4} \log ($ GDP per capita of country $d)+b_{5} \log$ (GDP per capita of country o)

$+\mathrm{b}_{6}$ Emigrants' human capital $(\mathrm{H})+\mathrm{b}_{7}$ Emigrants' human capital squared $\left(\mathrm{H}^{2}\right)+$ Time dummies

All but one of the explanatory variables are different from those in the selection equation. Aside from econometric considerations, notably the exclusion restriction mentioned earlier, 
the choice of these specific variables is rationalized by the model developed in this paper, based on equation (11).

Empirical results based on Heckman's 2-step (H2S) or maximum likelihood (HML) estimation technique, and on a Poisson Pseudo-Maximum Likelihood (PPML) estimation method are reported in the three columns on the right side of Table 2. Only the signs and significance levels can be compared, since the first two estimates (H2S, HML) are based on a log-linearized model whereas the last estimate (PPML) is based on a count model.

First, a larger labour force, residing at home or abroad $(p o p=m+n$ in equation 11) significantly increases bilateral remittances for all three estimation procedures, with an elasticity about equal to 1.5 for the two log-linearized models.

This inverted-U relationship between the emigration ratio and the aggregate remittances at the national level is specified in the linear model by the two explanatory variables $\mathrm{R}$ and $\mathrm{R}^{2}$, whose estimated coefficients are both highly significant for all three estimation procedures. These semi-elasticities of $\mathrm{R}$ and $\mathrm{R}^{2}$ yield a maximum for aggregate remittances for a value of $\mathrm{R}$ about equal to 0.5 (obtained by setting to zero the derivative of the estimated linear function of $\mathrm{R}$ and $\mathrm{R}^{2}$ ). This value of $\mathrm{R}$ seems rather high to be of any practical importance for most countries, since the mean value for our sample is 0.065 . But many small countries have an emigration ratio close to or larger than 0.5 in 2010 : Samoa (2.45), Guyana (1.44), Albania (1.18), Tonga (1.13), Suriname (0.88), Cape Verde (0.87), Jamaica (0.82), St. Vincent and the Grenadines (0.77), Barbados (0.65), Malta (0.61), São Tomé and Príncipe (0.58), Fiji (0.54), Trinidad and Tobago (0.53), etc. This is also true for many regions, towns or villages of large countries, where the average national migration ratio is low, but where the regional ratio can be very high. This means that there are policy 
implications for such small nations or regions of larger nations where the emigration ratio is close to or exceeds the estimated value of 0.5 : an increasing national or regional diaspora may not increase, but rather decrease, aggregate remittances received, once this value of the emigration ratio is passed.

A rise in living standards in the destination country significantly raises aggregate remittances, with elasticity about equal to 1.8. However, a change in GDP per capita in the originating country has a small negative, yet almost insignificant impact on remittances, except for the PPML estimate.

A proxy for the average human capital $\mathrm{H}$ of a migrant from origin country "o" who reside in destination country " $\mathrm{d}$ ", is constructed by dividing the number of (bilateral) emigrants with tertiary education by the total number of (bilateral) migrants. The relationship between this proxy and aggregate remittances is specified as an inverted- $U$ curve, following Docquier, Rapoport, and Salomone (2012), who have shown that remittances tend to increase at first with the emigrant's human capital, but that very highly qualified emigrants tend to settle permanently and reunite their family at destination more often than less qualified emigrants. To account for this inverted-U curve, human capital is specified by the two variables $\mathrm{H}$ and $\mathrm{H}^{2}$ in the estimation procedure: the coefficient of $\mathrm{H}$ is significant and positive, and the coefficient of $\mathrm{H}^{2}$ is negative, yet only significant at a $10 \%$ level for the $\mathrm{HML}$ estimate, which only partially validates the inverted-U curve for human capital hypothesized by DRS. Indeed, the estimated coefficients of $\mathrm{H}$ and $\mathrm{H}^{2}$ would yield a maximum level of remittances for $\mathrm{H}$ equal to a very high percentage of tertiary-educated migrants of $84 \%$, which is rare in our sample. 


\section{Conclusion and Policy Implications}

As aggregate remittances increase steadily worldwide, some small countries or regions where the emigration rate has been historically very high, with a diaspora that has been settled abroad for many generations, such as Malta, Cyprus, Portugal, the Cook Islands, Wallis and Futuna, now experience stable or even declining aggregate remittances, even though the diaspora is still very large compared to the resident population. In other words, a growing diaspora does not always imply more aggregate remittances, especially when the income gap between migrants and non-migrants decreases as times passes, due to the convergence of the origin and host economies.

Our theory of the family coalition with either altruism or a social reciprocity norm cum bargaining predicts that the remittance sent per emigrant is inversely related to the number of emigrant remitters per family, ceteris paribus, giving rise to an inverted-U shaped pattern for total remittances received in the country of origin when the emigration ratio (diaspora/population at origin) increases.

Using a database of bilateral remittance flows for about 6000 observations, this prediction of our model is validated by the empirical results, based on a two-stage Heckman selection model and three different estimation procedures.

In the first-stage selection equation, we also find strong evidence in favour of the positive impact of the volume of migration and the standard of living on the probability to remit, and we uncover a significant negative effect of bilateral distances between countries and the cost of sending money abroad on the likelihood of remittances.

In the second-stage equation, we find strong evidence for an inverted-U relationship between aggregate remittances and the emigration ratio R (i.e., diaspora to labour force at origin). Less evidence is found for a second inverted-U relationship between aggregate remittances and migrants' human capital. An increase in the labour force, a rise in per capita 
GDP in the destination country also significantly raise bilateral aggregate remittances, as the model predicts.

The finding of an inverted-U curve for aggregate remittances as a function of the emigration ratio validates the theory of remittances as a family coalition decision (with either altruism or bargaining).

Our findings have important policy consequences for migrant sending countries, regions, towns or villages with a very high emigration ratio: as the diaspora grows, the amount received per recipient at home tends to increase less and less, and the total amount received may at a point reach a maximum and then decrease as more and more families are progressively reunited abroad.

Our estimates show that once the ratio of diaspora to the adult population at origin exceeds $50 \%$, there are decreasing returns to emigration: aggregate remittances may then decline as the emigration ratio increases. Many small nations (most of them islands) are close to or already exceed this value.

If such national or local governments want to maximise aggregate remittances received, they should not encourage further emigration.

Furthermore, this is more likely to happen in regions or countries that have already become very dependent on such transfers from abroad. As seen above, it is likely that the following countries with high emigration ratios may already be on the declining side of their aggregate remittance curve. Indeed, for those countries, diaspora growth is no longer synonymous with aggregate remittance growth. 


\section{References}

Agarwal, R. and A.W. Horowitz. 2002. "Are international remittances altruism or insurance? Evidence from Guyana using multiple-migrant households", World Development, 11: 20332044.

Amuedo-Dorantesa, C., S. Pozob, and C. Vargas-Silvac. 2010. "Remittances in Small Island Developing States", The Journal of Development Studies, 46: 941-960

Anderson, J.E. 2011. “The Gravity Model”, Annual Review of Economics, 3: 133-160.

Artuc E., F. Docquier, C. Özden, and C. Parsons. 2015. "A global assessment of human capital mobility: The role of non-OECD destinations", World Development, 65: 6-26.

Beine, M., S. Bertoli, and J. Fernandez-Huertas Moraga. 2014. “A practitioners' guide to gravity model of international migration”, FERDI Policy Brief, 102.

Bernheim B.D, Shleifer A., and L.H. Summers. 1985. "The Strategic Bequest Motive", Journal of Political Economy, 93: 1045-76.

Bertram G. and R.F. Watters.1985. "The MIRAB economy in South Pacific microstates", Pacific Viewpoint 26 (3): 497-519.

Bettin, G., and R. Lucchetti. 2016. "Steady streams and sudden bursts: persistence patterns in remittance decisions", Journal of Population Economics, 29: 263-292.

Brown, R. 1997. "Estimating remittance functions for Pacific island migrants", World Development, 25 (4): 613-626.

Brown R. and B. Poirine. 2005., "A model of migrants' remittances with human capital investment and intra-familial transfers", International migration Review, 39: 407-438.

Brown, R., G. Leevesb, and P. Prayaga. 2014. "Sharing Norm Pressures and Community Remittances: Evidence from a Natural Disaster in the Pacific Islands", The Journal of Development Studies, 50: 383-398

Brown, R., and E. Jimenez-Soto. 2015. "Migration and Remittances". in Chiswick, B.R., and Miller, P.W. (eds), Handbook of the Economics of International Migration, volume 1, Elsevier, 1077-1140.

Carling J. 2014. "Scripting Remittances: Making Sense of Money Transfers in Transnational Relationships", International Migration Review, 48 (Fall): S218-S262

CEPII (Centre d'Études Prospectives et d'Informations Internationales), “Databases". 2014. Accessed June 8, 2014.

http://www.cepii.fr/cepii/en/bdd_modele/bdd.asp

Clemens M. and T. Ogden. 2013. Migration as a Strategy for Household Finance: A research agenda on remittances, payments, and development. FAI working paper 10/2013, New York University,

Cox D. 1987. "Motives for private income transfers", Journal of Political Economy, 95: 508546. 
Cox D., and M. Rank. 1992. "Inter-vivos transfers and intergenerational exchange", Review of Economics and Statistics, 74: 305-314.

Cox D., S. Eser, and E. Jimenez. 1998. "Motives for private transfers over the life cycle: an analytical framework and evidence for Peru", Journal of Development Economics, 55: 57-80.

De la Croix, D., F. Docquier, and M. Schiff. 2014. "Brain Drain and Economic Performance in Small Island Developing States". in Artal-Tur, A., G. Peri, and F. Requena-Silvente (eds), The Socio-Economic Impact of Migration flows - Effects on Trade, Remittances, Output, and the Labour Market, Population Economics series, Springer, 123-144.

Docquier F. and H. Rapoport. 2006. "The Economics of Migrants' Remittances", Handbook of the Economics of Giving, Altruism and Reciprocity, 1: 1135-1198.

Docquier F., H. Rapoport, and S. Salomone. 2012. "Remittances, migrants' education and immigration policy: Theory and evidence from bilateral data", Regional Science and urban economics, 42: 817-828.

Docquier F., Peri G., and I. Ruyssen. 2014. "The Cross-country Determinants of Potential and Actual Migration”, International Migration Review, 48: S37-S99.

Docquier F. 2014. "International migration data sets".

Accessed June 8, 2014.

http://perso.uclouvain.be/frederic.docquier/oxlight.htm

Feeny, S., S. Iamsiaroj, and M. McGillivray. 2014. "Remittances and Economic Growth: Larger Impacts in Smaller Countries?", The Journal of Development Studies, 50: 1055-1066

Frankel J., 2011. “Are bilateral remittances countercyclical?”, Open Economies Review 22(1): $1-16$.

Freund, C., and N. Spatafora. 2008. "Remittances, transaction costs, and informality", Journal of Development Economics, 86: 356-366.

Head, K. and T. Mayer. 2014. "Gravity Equations: Workhorse, Toolkit, and Cookbook", Handbook of International Economics, 4: 131-195.

Helpman, E., M.J. Melitz, and Y. Rubinstein. 2008. "Estimating Trade Flows: Trading Partners and Trading Volumes", Quarterly Journal of Economics, 123: 441-487.

International Monetary Fund. 2014. "World Economic Outlook Database".

Accessed June 8, 2014.

https://www.imf.org/external/pubs/ft/weo/2014/01/weodata/index.aspx

Johnson G.E. and W.E. Whitelaw.1974. "Urban-Rural Income Transfers in a Developing Country: The Case of Kenya, An Estimated-Remittances Function”, Economic Development and Cultural Change, 22: 473-479.

Lucas R. and O. Stark.1985. "Motivations to Remit: Evidence from Botswana", Journal of Political Economy, 93 (50): 901-918.

Lueth, E., and M. Ruiz-Arranz. 2008. "Determinants of bilateral remittance flows". B.E. Journal of Macroeconomics 8 (1): 1-23. 
Osili U.O. 2007. "Remittances and savings from international migration: Theory and evidence using a matched sample", Journal of Development Economics 83: 446-465.

Park C. 2003. "Are children repaying parental loans? Evidence from Malaysia using matched child-parent pairs". Journal of Population Economics, 16: 243-263.

Poirine, B. 1997. "A Theory of Remittances as an Implicit Family Loan Arrangement", World Development, 25 (4): 589-611.

Poirine B. 2006. "Remittances sent by a growing altruistic diaspora: How do they grow over time?", Asia Pacific Viewpoint, 47 (1): 93-108.

Rempel, H., and R. Lobdell. 1978. "The Role of Urban to Rural Remittances in Rural Development”, Journal of Development Studies 14: 324-41.

Regmi G., and C. Tisdell. 2002. "Remitting behaviour of Nepalese rural-to-urban migrants: implications for theory and policy", Journal of Development Studies, 38 (3): 76-94.

Santos Silva, J., and S. Tenreyro. 2006. "The log of gravity", The Review of Economics and Statistics, 88 (4): 641-658.

Santos Silva, J., and S. Tenreyro. 2010. "On the existence of the maximum likelihood estimates in Poisson regression", Economics Letters 107: 310-312.

Santos Silva, J., and S. Tenreyro. 2011. "Further Simulation Evidence on the Performance of the Poisson-PML Estimator", Economics Letters 112: 220-222.

Schioupu, I., and N. Siegfried., 2006. "Determinants of workers' remittances. Evidence from the European neighbouring region", European Central Bank Working Paper Series, No 688 (October).

Stark O., and D. Levhari. 1982. "On migration and risk in LDCs", Economic Development and Cultural Change, 31: 191-196.

Stark O., and D. E. Bloom.1985. "The new Economics of labour migration", The American Economic Review, Papers and proceedings of the Ninety-Seventh Annual Meeting of the American Economic Association, 75 (2): 173-178.

Stark O. 1991., The migration of labour, Wiley-Blackwell.

World Bank 2015. Migration and Remittances Factbook 2016, 3rd edition

World Bank 2015. Migration and Development Brief, 24, 25.

Yang D. 2011. "Migrant remittances", The Journal of Economic Perspectives, 25(3): 129151. 